\title{
Moving beyond anti-amyloid therapy for the prevention and treatment of Alzheimer's disease
}

\author{
Michael A Castello, John David Jeppson and Salvador Soriano*
}

\begin{abstract}
Background: High-profile Phase 3 clinical trials of bapineuzumab and solanezumab, antibodies targeted at amyloid-beta $(A \beta)$ removal, have failed to meet their primary endpoints. Neither drug improves clinical outcomes in patients with late onset $A D$, joining a long list of unsuccessful attempts to treat $A D$ with anti-amyloid therapies.

Discussion: These therapies are based on the assumption that $A \beta$ accumulation is the primary pathogenic trigger of $A D$. Current evidence suggests that $A \beta$ may actually accumulate as part of an adaptive response to long-term chronic brain stress stimuli that would make more suitable candidates for therapeutic intervention.

Summary: At this juncture it is no longer unreasonable to suggest that further iterations of anti-A $\beta$ therapies should be halted. Clinicians and researchers should instead direct their attention toward greater understanding of the biological function of $A \beta$ both in healthy and demented brains, as well as the involvement of long-term chronic exposure to stress in the etiology of $A D$.
\end{abstract}

Keywords: Late onset Alzheimer's disease, Amyloid cascade hypothesis, Anti-amyloid therapy, Amyloid beta, Familial Alzheimer's disease, Solanezumab, Bapineuzumab, Cholesterol metabolism, Dementia, Neurodegeneration

\section{Background}

According to reports published in the New England Journal of Medicine, the phase 3 clinical trials of two high-profile Alzheimer's disease (AD) antibodies against the aggregation-prone peptide amyloid beta $(\mathrm{A} \beta)$, bapineuzumab and solanezumab, have failed to improve clinical outcomes in patients with late onset $\mathrm{AD}$ [1-3]. Along with their predecessors, these treatments have been informed by the long-standing amyloid hypothesis, and are the latest examples in a long list of unsuccessful attempts to treat AD with anti-amyloid therapies. Along with a chorus of others, we have previously argued against the assumption that $A \beta$ accumulation is the primary early pathogenic trigger of $\mathrm{AD}$ [4-8]. An unintended consequence of that assumption, which contributes to the continued failure of anti-amyloid clinical trials, is that affirmative diagnosis of AD-type dementia can only occur when the presence of $A \beta$ accumulation in the brain is confirmed. However, recent imaging studies confirm previous observations of $\mathrm{A} \beta$ accumulation in a significant proportion of non-demented individuals $[4,9,10]$. Conversely, a sizable proportion of patients

\footnotetext{
* Correspondence: ssoriano@llu.edu

Department of Anatomy, Loma Linda University School of Medicine, Evans Hall B08, 24785 Stewart Street, Loma Linda, CA 92354, USA
}

clinically diagnosed with $A D$ do not display $\mathrm{A} \beta$ accumulation-even though neurodegeneration is in progress $[4,11]$. Remarkably, rather than concluding that $A \beta$ status is not a reliable marker for the early stages of clinical $\mathrm{AD}$, a consensus has been reached in which clinically diagnosed $A D$ patients without $A \beta$ are classified as not suffering from $\mathrm{AD}$. This line of thought is not scientifically warranted, as there is no evidence to assume that clinical $\mathrm{AD}$ cases with and without $\mathrm{A} \beta$ accumulation are etiologically different. Nevertheless, it has been used, in the EXPEDITION 3 phase of the ongoing solanezumab trial, to justify the exclusion of approximately $25 \%$ of patients in the study-all of whom were clinically diagnosed with mild $A D$, but whose imaging data showed no $\mathrm{A} \beta$ accumulation $[1,3]$.

\section{Discussion}

We submit that such course of action is logically flawed on two different fronts. Firstly, current imaging methods cannot detect the soluble $A \beta$ oligomers that solanezumab is thought to remove but that are, according to the amyloid hypothesis itself, the bona fide pathogenic trigger of the disease [12-14]. Thus, by eliminating all patients diagnosed with clinical $\mathrm{AD}$ but lacking $\mathrm{A} \beta$ plaques, all the subjects that would potentially benefit from the trial are 
effectively removed. Secondly, there is no obvious rationale for following patients in whom $\mathrm{A} \beta$ plaques are already detectable, since the presence of those plaques occurs, according to the amyloid hypothesis itself, too late in the disease for treatment to be effective and does not necessarily correlate with neurodegeneration [3,12-18]. In effect, the current course of action helps to perpetuate a tautological argument: the a priori assumption that $A \beta$ is the cause of $\mathrm{AD}$ is used to reject any clinical case in which no $\mathrm{A} \beta$ increase is apparent.

Figure 1 further illustrates what we believe is the flawed rationale on which anti-amyloid clinical trials are based. Cognitive status assessment and $A \beta$ imaging data lead, according to the amyloid hypothesis, to a division of the population into four distinct groups (Figure 1A), which are: patients who are cognitively healthy (normal cognition, NC; Figure 1A, 4), patients who are cognitively healthy but accumulate $A \beta$ (normal cognition with $A \beta$, $\mathrm{NC}-\mathrm{A} \beta$; Figure $1 \mathrm{~A}, 2)$, patients with neurodegeneration who have clinical AD symptoms but no $A \beta$ accumulation (neurodegeneration-first AD, NDF-AD; Figure 1A, 3), and finally, patients who have neurodegeneration, clinical AD symptoms, and $\mathrm{A} \beta$ accumulation ( $\mathrm{A} \beta$-first $\mathrm{AD}, \mathrm{AF}-\mathrm{AD}$; Figure $1 \mathrm{~A}, 5)[3,4,11]$. According to the amyloid hypothesis, of all the observed populations, only the latter can be considered, by definition, as suffering from dementia of the AD type, and only group 4 should be considered as appropriate normal cognition controls in clinical trials.

The ongoing insistence on failing anti-amyloid therapies is anchored on the belief that late onset AD primarily develops from aberrant $A \beta$ biology that results in its accumulation. When the amyloid hypothesis was formed, strong evidence clearly supported that assumption: Not only do all familial cases of AD involve APP mutations that cause dysregulated $\mathrm{A} \beta$ production, cases of trisomy 21 (Down syndrome; DS) in which APP was overexpressed also exhibit $A \beta$ plaque formation identical to that of $A D$ patients [19-21]. Since both FAD and DS exhibit pathology clearly linked to $\mathrm{A} \beta$ production, late onset $\mathrm{AD}$-which also has abnormal $A \beta$-must also begin with $A \beta$. Such a conclusion has subsequently been supported by innumerable animal and cell culture studies in which pathology is induced by $A \beta$ and rescued by its removal [22-25]. Given these findings, the thinking currently guiding $\mathrm{AD}$ clinical trials concludes that $\mathrm{A} \beta$-modifying therapies simply must be capable of preventing late-onset $\mathrm{AD}$ if administered correctly.

However, this line of reasoning does not account for numerous other current observations. For example, while all cases of FAD can be linked to a relatively small number of mutations directly affecting APP processing, this is never the case with late-onset $\mathrm{AD}[26,27]$. In fact, in the largest genetic analyses of late-onset $\mathrm{AD}$ to date, the polymorphisms commonly observed are nearly all associated with cholesterol metabolism, endocytosis (an essential part of cholesterol processing), and inflammation [28-30] This evidence, together with imaging studies showing that $A \beta$ accumulation can be uncoupled from disease initiation, strongly argue against $A \beta$ as an early pathogenic trigger of late onset $\mathrm{AD}$ and, therefore, as a suitable therapeutic target [9-11].
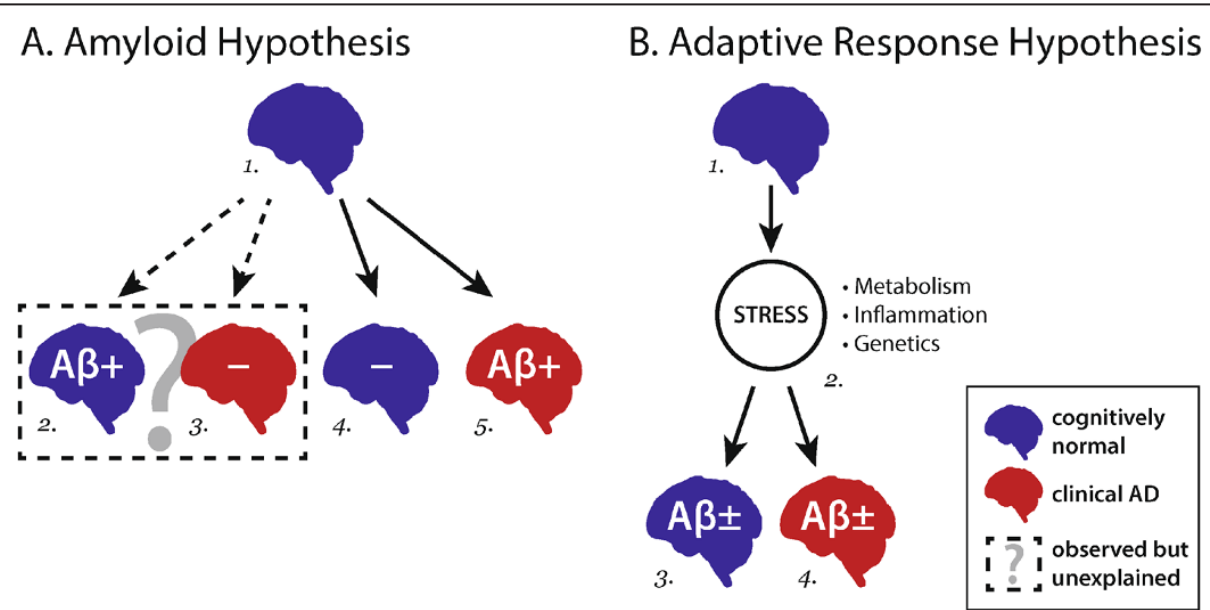

Figure 1 Comparison of the amyloid and adaptive response hypotheses. A. Amyloid Hypothesis Cognitive tests and amyloid imaging separate the total population into four distinct groups (1). These groups are: Normal Cognition (NC; 4), NC with $A \beta$ accumulation (NC-A ; 2 ), Neurodegeneration-First AD (NDF-AD; 3), and Amyloid-First AD (AF-AD; 5). Under this hypothesis, only the AF-AD and NC groups $(4,5)$ are going to be studied moving forward in EXPEDITION 3 as disease state and control, whereas the NC-A $\beta$ and NDF-AD groups $(2,3)$ are ignored, as they cannot be explained and do not fit the paradigm. B. Adaptive Response Hypothesis The total population (1) is differentiated by a set of stress variables (2) which may include, but are not limited to, oxidative stress, metabolism dysregulation (cholesterol homeostasis, insulin resistance, etc.), genetic factors, and inflammation response. These variables elicit an adaptive response in the brain and, depending on the nature and intensity of such response, the population falls into two groups, either Normal Cognition (NC) (3) or AD (4), both of which contain A $\beta$ positive and negative subpopulations. 
In our view, resolving the apparent contradictions in evidence begins with abandoning the assumption that $\mathrm{FAD}$ and late onset $\mathrm{AD}$ are etiologically comparable. Doing so will help create the right context for the study of the role of $A \beta$ in health and disease, a role we do not currently understand. In that regard, note that virtually every experimental in vitro and in vivo model demonstrating $A \beta$ harm and subsequent improvement upon its removal is, at best, a model of FAD. By definition, these models begin with the overexpression of $A \beta$ itself, a pathogenic course that does not occur in late onset $A D$ [22-25]. In contrast, if FAD were considered not as an accelerated version of late onset $\mathrm{AD}$, but rather as a subset of $\mathrm{AD}$ presentations that is etiologically different, we could begin to explore the bona fide pathogenic triggers of late onset $\mathrm{AD}$ and design evidence-based therapies.

In that regard, several hypotheses that are not amyloid-centric have been proposed, although few have gained significant traction [6,31-35]. Unlike in the past, however, numerous independent researchers have now gathered sufficient information to strongly support a reworked conceptualization of late onset AD. Our recently proposed Adaptive Response Hypothesis synthesizes this work, proposing that $A \beta$ may accumulate as part of an adaptive response to chronic brain stress stimuli [6]. These stress stimuli constitute the bona fide pathogenic triggers of late onset $\mathrm{AD}$ and, therefore, would be suitable candidates for therapeutic intervention $[5-7,32,36]$. In this model, illustrated in Figure 1B, the total population (Figure 1B, 1) can be affected by chronic stress stimuli (Figure 1B, 2) which may include, but are not limited to, oxidative stress, metabolic dysregulation (cholesterol homeostasis, insulin resistance, etc.), genetic factors, and inflammatory response [7,36]. Each of these stimuli is capable of eliciting a response in which $A \beta$ is produced, and the nature of that response (not the total amount of $A \beta$ that may accumulate in parallel) determines progression into clinical $\mathrm{AD}[5,6]$. Ultimately this leads to the observed division, shown in Figure 1B, into individuals with normal cognition (NC; Figure $1 B, 3$ ) and those clinically diagnosed with $A D$ (AD; Figure 1B, 4), both of which may be further divided into $A \beta$ positive and $A \beta$ negative subpopulations $[6,32]$.

According to this view, therapeutic approaches must address the biology of the chronic stressors that initiate the disease, not the $A \beta$ accumulation that (unlike in FAD) may, or may not, occur during the course of the disease. This offers numerous potential avenues to explore in the battle against $\mathrm{AD}$. In fact, research into aging, cholesterol regulation, and metabolic disorders such as diabetes all can potentially be applied to AD. Conceiving of the disease in this open-ended, systemic fashion will allow clinicians and scientists to identify new patterns and possibilities for therapy. For example, early research has shown that metabolism in the $\mathrm{AD}$ brain is aberrant in ways that are not currently looked for in the periphery $[37,38]$. Following this pathway, early treatment intranasal insulin has actually shown some promise in treating cognitive decline [38]. Similarly, might drugs enhancing neural plasticity empower the brain's stress response in old age? [39].

Finally, it is worth noting that anti-amyloid therapies may not simply result in neutral outcomes. Our hypothesis predicts that $A \beta$ removal will interfere with brain homeostasis, and mounting evidence suggests that wellregulated $A \beta$ is important for healthy brain functions such as memory formation-a function that is critical to clinical outcome measurements [40-43]. At the same time, even the most recent bapineuzumab trial continues to be limited by edema formation, a symptom highly associated with cerebral amyloid angiopathy, the damaging vascular amyloid deposition that often co-occurs with $\mathrm{AD}[2,3,44]$. Thus, the possibility must be considered that current therapies designed around the bulk removal of $\mathrm{A} \beta$ may not simply fail, but be actively harmful by hindering the very functionality they hope to preserve.

In summary, millions of research dollars, both private and public, are annually expended on anti-A $\beta$ therapies that do not work and are based on a logically flawed hypothesis. At this point in time it is no longer unreasonable to suggest that further iterations of anti-A $\beta$ therapies may not be in the best interest of late onset AD patients. Clinicians and researchers should instead direct their attention toward better understanding of the biological function of $A \beta$ in the healthy brain, and the ways in which chronic stress over decades can negatively affect the brain.

\section{Summary}

- The authors contend that the amyloid cascade hypothesis is no longer supported by the majority of experimental evidence

- Proposed elimination of patients from EXPEDITION 3 of the solanezumab Phase III trial based on $A \beta$ imaging is fundamentally flawed

- $A \beta$-centric therapeutic studies promote a tautological definition of Alzheimer's disease in which the a priori assumption that $A \beta$ is the primary causative factor is used to exclude patients exhibiting contrary symptoms

- An adaptive response hypothesis summarizes a diverse body of experimental evidence and is able to account for all AD-related presentations

- Such a hypothesis provides new opportunities for research and potential therapies that the amyloid cascade hypothesis does not 


\section{Abbreviations}

AD: Alzheimer's disease; FAD: Familial AD; AB: Amyloid beta; NC: Normal cognition; NC-A : Normal cognition with $A \beta$; NDF-AD: Neurodegeneration-first AD; AF-AD: Aß-first AD.

\section{Competing interests}

The authors have no competing interests to disclose.

\section{Authors' contributions}

MAC, JDJ, and SS each contributed to the writing, editing, and revision of the manuscript. All authors read and approved the final manuscript.

\section{Acknowledgements}

The authors are grateful to Kristy D. Howard for her support.

Received: 5 March 2014 Accepted: 18 August 2014

Published: 2 September 2014

\section{References}

1. Doody RS, Thomas RG, Farlow M, Iwatsubo T, Vellas B, Joffe S, Kieburtz K, Raman R, Sun X, Aisen PS, Siemers E, Liu-Seifert H, Mohs R: Phase 3 trials of solanezumab for mild-to-moderate Alzheimer's disease. N Engl J Med 2014, 370:311-321

2. Salloway S, Sperling R, Fox NC, Blennow K, Klunk W, Raskind M, Sabbagh M, Honig LS, Porsteinsson AP, Ferris S, Reichert M, Ketter N, Nejadnik B, Guenzler V, Miloslavsky M, Wang D, Lu Y, Lull J, Tudor IC, Liu E, Grundman $M$, Yuen E, Black R, Brashear HR: Two phase 3 trials of bapineuzumab in mild-to-moderate Alzheimer's disease. N Engl J Med 2014, 370:322-333.

3. Karran E, Hardy J: Antiamyloid therapy for Alzheimer's disease-Are we on the right road? N Engl J Med 2014, 370:377-378.

4. Jack CR, Wiste HJ, Weigand SD, Knopman DS, Lowe V, Vemuri P, Mielke MM, Jones DT, Senjem ML, Gunter JL, Gregg BE, Pankratz VS, Petersen RC Amyloid-first and neurodegeneration-first profiles characterize incident amyloid PET positivity. Neurology 2013, 81:1732-1740.

5. Herrup K: Reimagining Alzheimer's disease-an age-based hypothesis. J Neurosci 2010, 30:16755-16762.

6. Castello MA, Soriano S: Rational heterodoxy: cholesterol reformation of the amyloid doctrine. Ageing Res Rev 2013, 12:282-288.

7. Castello MA, Soriano S: On the origin of Alzheimer's disease. Trials and tribulations of the amyloid hypothesis. Ageing Res Rev 2014, 13C:10-12

8. Drachman DA: The amyloid hypothesis, time to move on: amyloid is the downstream result, not cause, of Alzheimer's disease. Alzheimers Dement J Alzheimers Assoc 2014, 10:372-380.

9. Hulette CM, Welsh-Bohmer KA, Murray MG, Saunders AM, Mash DC, Mclntyre LM: Neuropathological and neuropsychological changes in "normal" aging: evidence for preclinical Alzheimer disease in cognitively normal individuals. J Neuropathol Exp Neurol 1998, 57:1168-1174.

10. Aizenstein HJ, Nebes RD, Saxton JA, Price JC, Mathis CA, Tsopelas ND, Ziolko SK, James JA, Snitz BE, Houck PR, Bi W, Cohen AD, Lopresti BJ, DeKosky ST, Halligan EM, Klunk WE: Frequent amyloid deposition without significant cognitive impairment among the elderly. Arch Neurol 2008, 65:1509-1517.

11. Hyman BT, Phelps CH, Beach TG, Bigio EH, Cairns NJ, Carrillo MC, Dickson DW, Duyckaerts C, Frosch MP, Masliah E, Mirra SS, Nelson PT, Schneider JA, Thal DR, Thies B, Trojanowski JQ, Vinters HV, Montine TJ: National Institute on Aging-Alzheimer's Association guidelines for the neuropathologic assessment of Alzheimer's disease. Alzheimers Dement J Alzheimers Assoc 2012, 8:1-13.

12. Holland JP, Liang SH, Rotstein BH, Collier TL, Stephenson NA, Greguric I, Vasdev N: Alternative approaches for PET radiotracer development in Alzheimer's disease: imaging beyond plaque. J Label Compd Radiopharm 2014, 57:323-331.

13. Selkoe DJ: Soluble oligomers of the amyloid beta-protein impair synaptic plasticity and behavior. Behav Brain Res 2008, 192:106-113.

14. Esparza TJ, Zhao H, Cirrito JR, Cairns NJ, Bateman RJ, Holtzman DM, Brody $D L:$ Amyloid- $\beta$ oligomerization in Alzheimer dementia versus highpathology controls. Ann Neurol 2013, 73:104-119.

15. Salloway $S$, Sperling R, Keren R, Porsteinsson AP, Van Dyck CH, Tariot PN, Gilman S, Arnold D, Abushakra S, Hernandez C, Crans G, Liang E, Quinn G, Bairu M, Pastrak A, Cedarbaum JM, For the ELND005-AD201 Investigators: A phase 2 randomized trial of ELND005, scyllo-inositol, in mild to moderate Alzheimer disease. Neurology 2011, 77:1253-1262.
16. Golde TE, Schneider LS, Koo EH: Anti-aß therapeutics in Alzheimer's disease: the need for a paradigm shift. Neuron 2011, 69:203-213.

17. Knopman DS, Parisi JE, Salviati A, Floriach-Robert M, Boeve BF, Ivnik RJ, Smith GE, Dickson DW, Johnson KA, Petersen LE, McDonald WC, Braak H, Petersen RC: Neuropathology of cognitively normal elderly. J Neuropathol Exp Neurol 2003, 62:1087-1095.

18. Braak H, Thal DR, Ghebremedhin E, Del Tredici K: Stages of the pathologic process in Alzheimer disease: age categories from 1 to 100 years. J Neuropathol Exp Neurol 2011, 70:960-969.

19. Masters CL, Simms G, Weinman NA, Multhaup G, McDonald BL, Beyreuther $\mathrm{K}$ : Amyloid plaque core protein in Alzheimer disease and down syndrome. Proc Natl Acad Sci 1985, 82:4245-4249.

20. Goate A, Chartier-Harlin MC, Mullan M, Brown J, Crawford F, Fidani L, Giuffra $L$, Haynes A, Irving $N$, James L: Segregation of a missense mutation in the amyloid precursor protein gene with familial Alzheimer's disease. Nature 1991, 349:704-706.

21. Mullan M, Crawford F, Axelman K, Houlden H, Lilius L, Winblad B, Lannfelt L: A pathogenic mutation for probable Alzheimer's disease in the APP gene at the $\mathrm{N}$-terminus of $\beta$-amyloid. Nat Genet 1992, 1:345-347.

22. Jin M, Shepardson N, Yang T, Chen G, Walsh D, Selkoe DJ: Soluble amyloid beta-protein dimers isolated from Alzheimer cortex directly induce Tau hyperphosphorylation and neuritic degeneration. Proc Natl Acad Sci U S A 2011, 108:5819-5824.

23. Li C, Ebrahimi A, Schluesener H: Drug pipeline in neurodegeneration based on transgenic mice models of Alzheimer's disease. Ageing Res Rev 2013, 12:116-140.

24. Bloom GS: Amyloid- $\beta$ and tau: the trigger and bullet in Alzheimer disease pathogenesis. JAMA Neurol 2014, 71:505-508.

25. Bignante EA, Heredia F, Morfini G, Lorenzo A: Amyloid $\beta$ precursor protein as a molecular target for amyloid $\beta$-induced neuronal degeneration in Alzheimer's disease. Neurobiol Aging 2013, 34:2525-2537.

26. Hardy JA, Higgins GA: Alzheimer's disease: the amyloid cascade hypothesis. Science 1992, 256:184-185.

27. Blennow K, De Leon MJ, Zetterberg H: Alzheimer's disease. Lancet 2006 368:387-403.

28. Naj AC, Jun G, Beecham GW, Wang L-S, Vardarajan BN, Buros J, Gallins PJ, Buxbaum JD, Jarvik GP, Crane PK, Larson EB, Bird TD, Boeve BF, Graff-Radford NR, De Jager PL, Evans D, Schneider JA, Carrasquillo MM, Ertekin-Taner N, Younkin SG, Cruchaga C, Kauwe JSK, Nowotny P, Kramer P, Hardy J, Huentelman MJ, Myers AJ, Barmada MM, Demirci FY, Baldwin CT, et al: Common variants at MS4A4/MS4A6E, CD2AP, CD33 and EPHA1 are associated with late-onset Alzheimer's disease. Nat Genet 2011, 43:436-441.

29. Hollingworth P, Harold D, Sims R, Gerrish A, Lambert J-C, Carrasquillo MM, Abraham R, Hamshere ML, Pahwa JS, Moskvina V, Dowzell K, Jones N, Stretton A, Thomas C, Richards A, Ivanov D, Widdowson C, Chapman J, Lovestone S, Powell J, Proitsi P, Lupton MK, Brayne C, Rubinsztein DC, Gill M, Lawlor B, Lynch A, Brown KS, Passmore PA, Craig D, et al: Common variants at ABCA7, MS4A6A/MS4A4E, EPHA1, CD33 and CD2AP are associated with Alzheimer's disease. Nat Genet 2011, 43:429-435.

30. Bali J, Gheinani AH, Zurbriggen S, Rajendran L: Role of genes linked to sporadic Alzheimer's disease risk in the production of $\beta$-amyloid peptides. Proc Natl Acad Sci U S A 2012, 109:15307-15311.

31. Obrenovich ME, Joseph JA, Atwood CS, Perry G, Smith MA: Amyloid- $\beta$ : a (life) preserver for the brain. Neurobiol Aging 2002, 23:1097-1099.

32. Castellani RJ, Smith MA: Compounding artefacts with uncertainty, and an amyloid cascade hypothesis that is "too big to fail.". J Pathol 2011, 224:147-152.

33. Lee H, Zhu X, Castellani RJ, Nunomura A, Perry G, Smith MA: Amyloid-beta in Alzheimer disease: the null versus the alternate hypotheses. J Pharmacol Exp Ther 2007, 321:823-829.

34. Benilova I, Karran E, De Strooper B: The toxic A $\beta$ oligomer and Alzheimer's disease: an emperor in need of clothes. Nat Neurosci 2012, 15:349-357.

35. Marchesi VT: Alzheimer's dementia begins as a disease of small blood vessels, damaged by oxidative-induced inflammation and dysregulated amyloid metabolism: implications for early detection and therapy. FASEB J 2011, 25:5-13.

36. Stranahan AM, Mattson MP: Recruiting adaptive cellular stress responses for successful brain ageing. Nat Rev Neurosci 2012, 13:209-216.

37. Valdez CM, Phelix CF, Smith MA, Perry G, Santamaria F: Modeling cholesterol metabolism by gene expression profiling in the hippocampus. Mol Biosyst 2011, 7:1891-1901. 
38. Freiherr J, Hallschmid M, Frey WH 2nd, Brünner YF, Chapman CD, Hölscher C, Craft S, De Felice FG, Benedict C: Intranasal insulin as a treatment for Alzheimer's disease: a review of basic research and clinical evidence. CNS Drugs 2013, 27:505-514.

39. Gervain J, Vines BW, Chen LM, Seo RJ, Hensch TK, Werker JF, Young AH: Valproate reopens critical-period learning of absolute pitch. Front Syst Neurosci 2013, 7:102.

40. Puzzo D, Privitera L, Leznik E, Fà M, Staniszewski A, Palmeri A, Arancio O: Picomolar amyloid- $\beta$ positively modulates synaptic plasticity and memory in hippocampus. J Neurosci 2008, 28:14537-14545.

41. Garcia-Osta A, Alberini CM: Amyloid beta mediates memory formation. Learn Mem 2009, 16:267-272.

42. Morley JE, Farr SA: The role of amyloid-beta in the regulation of memory. Biochem Pharmacol 2014, 88:479-485.

43. Wang W, Mutka A-L, Zmrzljak UP, Rozman D, Tanila H, Gylling H, Remes AM, Huttunen $\mathrm{HJ}$, Ikonen E: Amyloid precursor protein $\alpha$ - and $\beta$-cleaved ectodomains exert opposing control of cholesterol homeostasis via SREBP2. FASEB J Off Publ Fed Am Soc Exp Biol 2014, 28:849-860.

44. Sperling R, Salloway S, Brooks DJ, Tampieri D, Barakos J, Fox NC, Raskind M, Sabbagh M, Honig LS, Porsteinsson AP, Lieberburg I, Arrighi HM, Morris KA, Lu Y, Liu E, Gregg KM, Brashear HR, Kinney GG, Black R, Grundman M: Amyloid-related imaging abnormalities in patients with Alzheimer's disease treated with bapineuzumab: a retrospective analysis. Lancet Neurol 2012, 11:241-249.

doi:10.1186/s12883-014-0169-0

Cite this article as: Castello et al: Moving beyond anti-amyloid therapy for the prevention and treatment of Alzheimer's disease. BMC Neurology 2014 14:169.

\section{Submit your next manuscript to BioMed Central and take full advantage of:}

- Convenient online submission

- Thorough peer review

- No space constraints or color figure charges

- Immediate publication on acceptance

- Inclusion in PubMed, CAS, Scopus and Google Scholar

- Research which is freely available for redistribution 